\title{
Demersal fish assemblages of Faroe Bank: species composition, distribution, biomass spectrum and diversity
}

\author{
Eyðfinn Magnussen
}

University of the Faroe Islands and Faroese Fishery Laboratory, Noatun 3, FO-100, Faroe Islands

\begin{abstract}
Sixty-one fish species were caught in 303 trawl hauls in annual spring bottom surveys between 1983 and 1996. Based on cluster analyses, the Faroe Bank fish fauna can be grouped into 3 assemblages: shallow, intermediate and deep assemblage. The boundaries of these assemblages are strongly connected to depth, whereas the relatively homogeneous oceanographic features have a relatively small influence. Although the total number of species is high, the 4 most common species make up more than $60 \%$, both of the total abundance and biomass. A change in species composition has occurred on the Faroe Bank during the last decades. The fish assemblage on the Faroe Bank is mainly boreal, but the occurrence of Arctic as well as Mediterranean species bears witness to the composite nature of the area. Distribution maps of the most common species are presented. The fish species are distributed regularly across the depth range from 95 to $771 \mathrm{~m}$. Preferred depth for the most common fish species are also given. The highest species diversity was found on the southwestern (1.295) and western sides of the Bank (1.261). Species diversity increased with depth and was highest at depths of $>500 \mathrm{~m}$. The highest evenness index (0.611) was found in the shallowest area.
\end{abstract}

KEY WORDS: Faroe Bank - Demersal fish assemblages · Species composition · Species-area relationship · Zoogeography $\cdot$ Preferred depth $\cdot$ Biomass spectra $\cdot$ Diversity $\cdot$ Evenness

\section{INTRODUCTION}

The Faroe Bank is located approximately $75 \mathrm{~km}$ Southwest of the Faroe Islands (Fig. 1). Due to the small size of the Faroe Bank and its position as a geographically well-defined and self-contained ecosystem surrounded by an oceanic environment, it is a very suitable area for marine biological studies. Furthermore, comprehensive sampling programs can be made within a manageable time schedule.

Inside the $200 \mathrm{~m}$ depth contour, the Faroe Bank covers an area of about $45 \times 90 \mathrm{~km}$ and its shallowest part is less than $100 \mathrm{~m}$ deep. Towards the northeast, it is separated from the Faroe shelf by the narrow $(20 \mathrm{~km})$

*E-mail: eydfinnm@setur.fo and deep (850 m) Faroe Bank Channel. Thereby, the Bank has many similarities with a seamount. Current measurements with satellite-tracked drogues on the Bank have shown that the water on the bank has anticyclonic circulation with 1 cycle lasting for about 1 mo (Hansen et al. 1991). However, hydrographic, nutrient and plankton measurements have indicated that the isolation of the water masses on the bank varies with time (Lastein 1992, Gaard \& Mortensen 1993).

The topographic and hydrographic features on Faroe Bank have led to the existence of a fairly isolated ecosystem. This isolation largely determines the character of the populations of fish and other organisms on the bank. Tagging experiments with cod have demonstrated that migration between Faroe Bank and other areas is very low (Strubberg 1916, 1933, Tåning 1940, Joensen 1956, Jones 1966) and morphological as well 


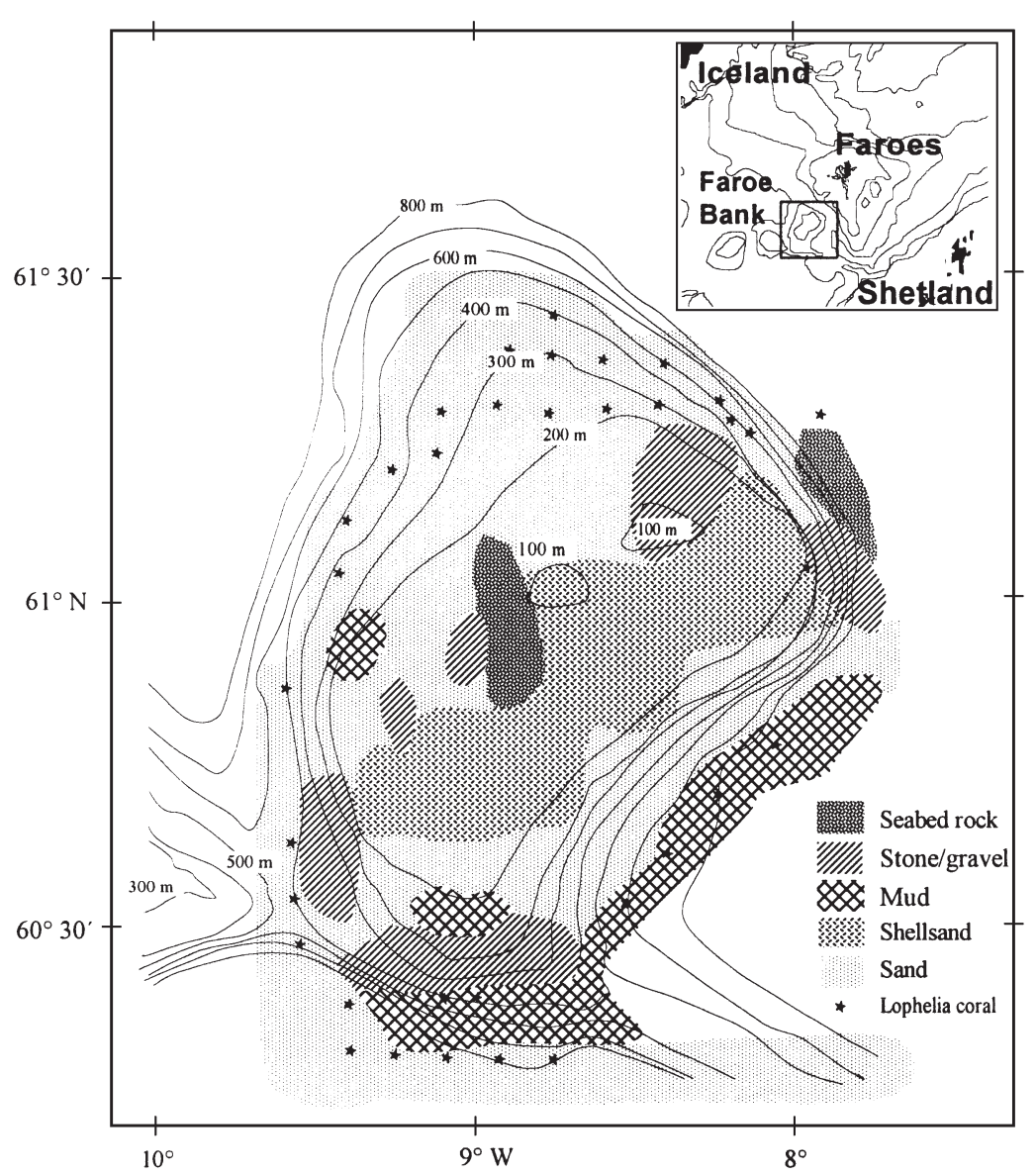

Fig. 1. Geographic location and seabed conditions of Faroe Bank

Plateau but rare on Faroe Bank. This indicates that the Bank is a separate ecosystem with regard to demersal fish as suggested by Jones (1966).

In fish biology, the main focus has traditionally been on providing advice for fishery management. Even though most of the research is focused on stock assessment, descriptions of benthic fish communities have been made, both of the fish assemblages (Gislason \& Helgason 1985, Gomes et al. 1992, Marrett \& Haedrich 1997, Mahon et al. 1998) and of the human impact on these (Daan et al. 1990, Greenstreet \& Hall 1996, Jennings \& Kaiser 1998, Hall 1999). The intention of this paper is to give a general description of the demersal fish assemblages on Faroe Bank including species composition and interactions, as well as geographic distribution and diversity.

\section{MATERIALS AND METHODS}

Study area. The front between Faroe Bank water masses and the open ocean is usually situated close to the $200 \mathrm{~m}$ bottom contour (Hansen et al. 1991). Within this contour Faroe Bank covers an area of approximately $3500 \mathrm{~km}^{2}$ (Table 1).

The general hydrographic condition around Faroe Bank has been reviewed by Hansen (1985) and Hansen \& Østerhus (2000). The

as biochemical differences have been confirmed for cod on the bank (Love et al. 1974). Growth rate of cod on Faroe Bank is higher than in most other areas (Ursin 1984, Fjallstein \& Magnussen 1996) and genetic differences based on DNA (Dahle 1995) and fatty acids (Joensen et al. 2000) have been demonstrated. For this reason the Faroe Bank cod stock is considered as a separate stock, which for all practical purposes does not mix with the nearby Faroe Plateau stock. Additionally, other fish species, e.g. haddock (Jones 1962), poor cod (Mattiangeli et al. 2000, 2001) and lemon sole (Rae 1939) are considered to be distinct from those on the Faroe Plateau, while other species on the bank are either not or rarely found on the Faroe Plateau (Joensen \& Tåning 1970). Bottom trawl surveys around the Faroe Islands (unpubl. data) have also demonstrated that there are large differences in the distribution pattern for several of the species living on Faroe Bank as compared to Faroe Plateau. For example, megrim only occurs on the bank whereas squid and poor cod, which are common on the bank, are rare on the plateau. In contrast, plaice is common on the Faroe area is characterised by a complex mixture of warm surface currents of Atlantic origin $\left(>7^{\circ} \mathrm{C}, 35.15\right.$ to $35.30 \%$ ) and, at greater depths, cold and less saline water masses of Arctic origin $\left(<0^{\circ} \mathrm{C}, 34.90\right.$ to $34.92 \%$ o). The warm and saline Atlantic water masses flow over either slope of the bank in a northward and eastward direction. On the southern side of the bank the whole water column is constituted by this water mass from the surface to bottom. At an depth below $500 \mathrm{~m}$ in the

Table 1. Size of Faroe Bank within different depth contours

\begin{tabular}{|lccrr|}
\hline $\begin{array}{l}\text { Depth range } \\
(\mathrm{m})\end{array}$ & $\begin{array}{c}\text { NE-SW } \\
\text { extension } \\
(\mathrm{km})\end{array}$ & $\begin{array}{c}\text { NW-SE } \\
\text { extension } \\
(\mathrm{km})\end{array}$ & \multicolumn{2}{c|}{ Area } \\
& $\left(\mathrm{km}^{2}\right)$ & $(\%)$ \\
\hline$<100$ & 20 & 7 & 125 & 1 \\
$100-200$ & 86 & 44 & 3510 & 33 \\
$200-300$ & 91 & 52 & 1372 & 13 \\
$300-400$ & 94 & 63 & 1082 & 10 \\
$400-500$ & 106 & 74 & 1412 & 13 \\
$>500$ & 116 & 109 & 3129 & 29 \\
\hline
\end{tabular}


Faroe Bank Channel, and on the eastern side of the bank, the water mass consists of cold Norwegian Sea water (Hansen \& Kristiansen 1999). Hence, water masses on Faroe Bank are of both Arctic and boreal origin. Temperature measurements (unpubl. data) show that the bottom temperature on Faroe Bank in March is mainly between 7.5 to $8.0^{\circ} \mathrm{C}$ and in September between 8.5 to $11^{\circ} \mathrm{C}$. Bottom temperature conditions on the bank are fairly homogeneous at any given time and depth. Because of atmospheric cooling the lowest temperature in March is on the shallowest part of the bank and the highest temperature is in deeper water. In September it is opposite. Faroe Bank has strong currents. Current amplitude of the $\mathrm{M}_{2}$ constituent is in the range from 29 to $37 \mathrm{~cm}$ $\mathrm{s}^{-1}$ and $\mathrm{S}_{2}$ is 10 to $11 \mathrm{~cm} \mathrm{~s}^{-1}$ (Simonsen 1999). The strong tidal current reduces the stratification on the bank compared to more open waters, but still the bank may have some stratification during summer (Lastein 1992).

The seabed condition on Faroe Bank is shown in Fig. 1. This map is based on information collected from inquiry forms answered by Faroese fishermen as well as available scientific material (Frederiksen et al. 1992, Nørrevang et al. 1994). The seabed mostly consists of sand with some spots of pebbles, stones and limited areas with seabed rocks. At depths of less than $200 \mathrm{~m}$, shell sand predominates. On the slope around the bank at depths of more than $200 \mathrm{~m}$, we find the scleractinian coral Lophelia pertusa (Frederiksen et al. 1992). Soft bottom areas dominate the slope on the south and southeast side of Faroe Bank.

Sampling. This paper analyses data from bottom trawl surveys on Faroe Bank which have routinely been carried out by RV 'Magnus Heinason' since 1983 (Fig. 2). To minimise annual variation, only trawl hauls taken in spring have been included in the analysis. From 1983 to 1996, 303 trawling stations were sampled on Faroe Bank, of which 273 had tow durations of between 50 and $80 \mathrm{~min}$. The surveys on Faroe Bank were mainly designed to study cod, haddock and saithe. Because of this, most stations are within the $200 \mathrm{~m}$ depth contour. To carry out surveys on Faroe Bank, the area is divided into 128 statistical squares of equal size, 5' latitude $\times 10^{\prime}$ longitude corresponding to approximately $5 \times 5 \mathrm{n}$ miles.

From 1983 to 1991 and again in 1996, the surveys were carried out in the second half of February and in March. In 1992, the surveys were in mid-February and again in mid-April. In 1993 to 1995, they were in April and May. The numbers of trawl stations varied during this period. Until 1991, the station number varied between 10 and 22. After that, the number was between 37 and 55 stations. Before 1993, stations were randomly positioned but since then they have been fixed. This survey design has resulted in an unequal distribution of trawl hauls in the research area (Fig. 2).

In all the years examined here, the same type of trawl was used: a 116-foot (35.4 m) 4-panel trawl with $18 \mathrm{~m}$ between ground wings and $40 \mathrm{~mm}$ nominal mesh size in the codend. To reduce possible effects from diel migration, the time of fishing was between 06:30 and 18:30 h. Tows were usually of $60 \mathrm{~min}$ duration. Towing speed was approximately 3 knots giving a swept area of approximately $100000 \mathrm{~m}^{2}$.

Data analysis. The species list is based on all 303 hauls, while the quantitative analyses only include tows with durations between 50 and $80 \mathrm{~min}$. Where possible, allocation of fish to zoogeographic group follows Joensen \& Tåning (1970), otherwise Whitehead et al. (1984) was used. The limited number of trawl hauls did not allow a statistical test of species composition and distribution by squares. Instead, analyses are based on main areas that squares were grouped into (Fig. 2). Homogeneity in geographic distribution of each species was tested by a $\chi^{2}$-test using frequencies of occurrence in main areas. Because of the great dis- 
similarity in depth between the shallower Area A and the other main areas, Area A was not analysed. To check for a north-south gradient in species distribution, the Main Areas B and E were tested against Areas $\mathrm{C}$ and D. East-west gradient was tested comparing Main Areas B and C against Areas D and E. The tow depths used in the analysis are averages of initial and final depth. For some of the analyses, data are grouped into $100 \mathrm{~m}$ depth zones. Biomass spectra were integrated by plotting the proportion of total biomass, regardless of species, of various size classes, defined as $\log _{2}$ of the mean body weight. To do this, length units were converted to weights using the length-weight relationship described in Magnussen (unpubl.), and Coull (1989) when available. Otherwise information from the fish-database on the Faroese Fishery Laboratory was used. Statistical analyses were carried out using the SYSTAT 8.0 program package (SYSTAT 1998). Cluster analyses were based on average numbers of fish caught in each square using Pearson's correlation coefficient with complete linkages. The preferred depth for each species was calculated as the average of initial and final fishing depth of each trawl haul weighted by the weight of the respective fish species caught in the haul. The Shannon species diversity index $(H)$ was calculated as:

$$
H=-\sum_{i=1}^{s} p_{i} \ln p_{i}
$$

where $p_{i}$ is the proportion of the $i$ th species caught on each station, $S$ is the number of species in the sample. Evenness, which is a measurement of how evenly the species composition is distributed, was calculated as:

$$
\text { Evenness }=\frac{H}{H_{\max }}
$$

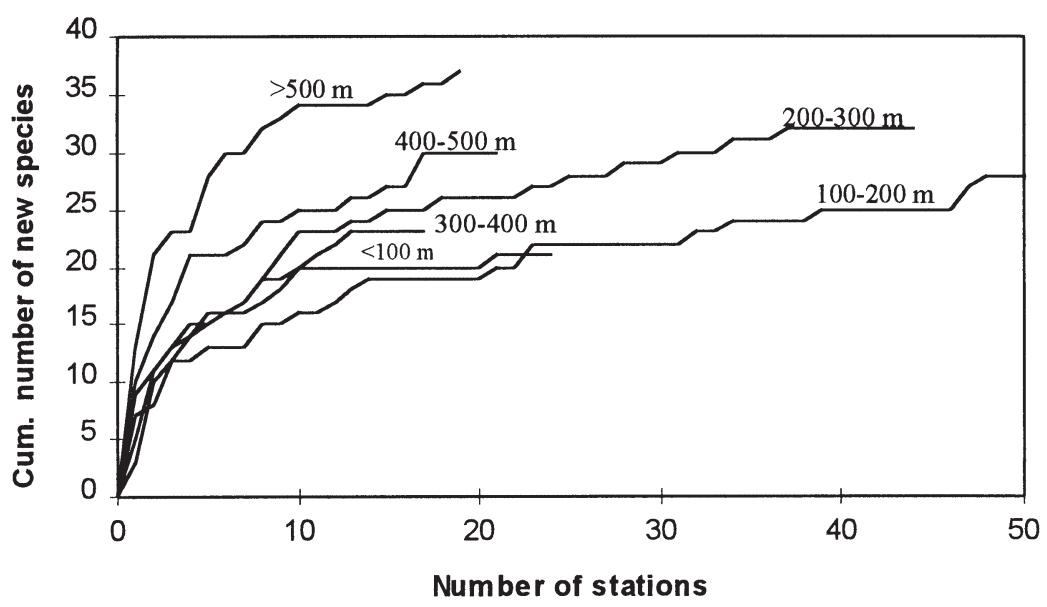

Fig. 3. Cumulative number of new species as a function of number of trawl hauls at depth intervals of $100 \mathrm{~m}$ from 94 to $771 \mathrm{~m}$. The curve for 100 to $200 \mathrm{~m}$ continues to 178 stations, at which point the ordinate is 43 species
Shannon and evenness indices were calculated for each trawl haul. Average values were compared between the 5 main areas with Kruskal-Wallis test and for a north-south and east-west gradient with MannWhitney $U$-test. The relationship of Shannon and evenness indices to depth was investigated by linear regression and the slope tested for the difference from 0 .

\section{RESULTS}

\section{Species composition}

A total number of 61 fish and squid species were caught (Table 2). Fish were caught at all depths from the shallowest area on the central bank $(92 \mathrm{~m})$ to the deep slope areas (901 m).

Table 2 lists the species together with their zoogeographic group and depth range. The only invertebrates considered to be sufficiently well sampled by the trawl gear were squid and European flying squid, which are included in this analysis. Of the 61 species caught, 4 are associated with the Arctic zoogeographic area, 30 are boreal, 3 are Arctic-boreal, 24 are Mediterranean-Atlantic or Mediterranean-boreal. Four of the species are East Atlantic with their northwesterly boundary at the Faroe Islands.

Plots with cumulative species number as a function of number of trawl hauls (Fig. 3) provide a clue to species heterogeneity in the investigation area. The total cumulative number of species by tow indicates the richness in the area. That number may be reached quickly if the area is quite homogeneous and slowly if it is heterogeneous. Even with 303 hauls, further species were still encountered on Faroe Bank. There were differences in the pattern of species composition at the 6 depth zones. Species richness increased with depth and was highest at a depth of more than $500 \mathrm{~m}$. In spite of the fact that there were only 19 tows at depths more than 500 m, 37 different species were caught, compared to 43 species in 178 hauls at depths between 100 and $200 \mathrm{~m}$. Increase in species richness with depth can partially be explained by an increase in area at larger depth. According to the theory of island biogeography (Pianka 1988), the species-area relationship can be described by the equation $S=C A^{z}$, where $S$ is the number of species, $\mathrm{C}$ is a constant, $A$ is the area and $z$ is the slope of the loglog regression. Including all tows at each depth zone the equation for the Faroe 
Table 2. List of fish and squid species caught on Faroe Bank in bottom-trawl surveys from 1983 to 1996 . Number of trawl hauls within each depth zone is shown below. The symbols used for commonness at each depth zone is: +++: Caught in 60 to $100 \%$ of the hauls; ++ 10 to $60 \%$; +: 3 to $10 \%$; ( ): Caught in less than $3 \%$ of the hauls; and -: not found. Abbreviations for the zoogeographic group are: A: Arctic species. B: Boreal species. AB: Arctic-boreal species. MAB: Mediterranean-Atlantic or Mediterranean-boreal. EA: East Atlantic species with their northwesterly boundary at the Faroes

\begin{tabular}{|c|c|c|c|c|c|c|c|c|c|}
\hline \multirow{2}{*}{ Species } & & \multirow{2}{*}{$\begin{array}{c}\text { Zoogeogr. } \\
\text { group }\end{array}$} & \multirow[b]{2}{*}{$<100$} & \multirow[b]{2}{*}{$100-200$} & \multirow{2}{*}{ D D } & \multirow{2}{*}{$\begin{array}{c}\text { pth zone } \\
300-400\end{array}$} & \multirow{2}{*}{ m) } & \multirow[b]{2}{*}{$>500$} & \multirow[b]{2}{*}{ Total } \\
\hline & & & & & & & & & \\
\hline Black-mouthed dog fish & Galeus melastomus & MAB, EA & - & ( ) & + & + & ++ & ++ & + \\
\hline Tope & Galeorhinus galeus & MAB & - & ( ) & - & - & - & + & ( ) \\
\hline Spur-dog & Squalus acanthias & MAB & - & + & + & ++ & + & ++ & + \\
\hline Velvet belly & Etmopterus spinax & MAB & - & ( ) & - & - & + & ++ & + \\
\hline Black dogfish & Centroscyllium fabricii & B & - & - & - & - & + & - & ( ) \\
\hline Starry ray & Raja radiata & B & - & - & - & - & - & ++ & ( ) \\
\hline Skate & Raja batis & B & - & + & + & - & - & ++ & + \\
\hline Shagreen ray & Raja fullonica & B & - & ( ) & ( ) & - & - & + & ( ) \\
\hline Sandy ray & Raja circularis & MAB, EA & - & - & + & - & - & - & ( ) \\
\hline Round skate & Raja fyllae & B & - & ( ) & - & - & - & - & ( ) \\
\hline Sail ray & Raja lintea & B & + & ( ) & - & - & - & - & ( ) \\
\hline Thornback ray & Raja clavata & MAB & - & ( ) & - & - & - & - & ( ) \\
\hline Rabbit fish & Chimaera monstrosa & MAB & + & + & ++ & +++ & +++ & +++ & ++ \\
\hline Snipe-eel & Nemicthys scolopaceus & MAB & - & ( ) & - & - & - & - & ( ) \\
\hline Herring & Clupea harengus & B & - & - & - & + & - & - & ( ) \\
\hline Greater silver smelt & Argentina silus & B & - & + & ++ & +++ & +++ & +++ & ++ \\
\hline Blent snout & Xenodermichthys copei & B & - & ( ) & - & - & + & - & ( ) \\
\hline Anglerfish & Lophius piscatorius & MAB & ++ & ++ & + & + & + & ++ & ++ \\
\hline North Atlantic codling & Lepidion eques & B & - & - & - & - & - & ++ & ( ) \\
\hline Cod & Gadus morhua & B & +++ & +++ & ++ & - & + & - & +++ \\
\hline Saithe & Pollachius virens & B & ++ & +++ & +++ & +++ & +++ & ++ & +++ \\
\hline Tusk & Brosme brosme & B & - & + & ++ & +++ & +++ & ++ & ++ \\
\hline Haddock & Melanogrammus aeglefinus & B & +++ & +++ & +++ & +++ & + & ++ & +++ \\
\hline Greater fork-beard & Phycis blennoides & MAB & - & - & - & - & ++ & ++ & ( ) \\
\hline Poor cod & Trisopterus minutus & B, EA & +++ & ++ & ++ & ++ & + & ++ & ++ \\
\hline Ling & Molva molva & B & +++ & +++ & +++ & +++ & +++ & ++ & +++ \\
\hline Blue ling & Molva dipterygia & B & - & - & - & + & ++ & +++ & + \\
\hline Silvery pout & Gadiculus argenteus thori & B & - & ( ) & + & ++ & ++ & ++ & + \\
\hline Blue whiting & Micromesistius poutassou & MAB & - & ( ) & ++ & +++ & +++ & +++ & ++ \\
\hline Whiting & Merlangus merlangus & MAB & - & ( ) & + & - & - & - & ( ) \\
\hline Common mora & Mora moro & MAB & - & - & - & - & - & + & ( ) \\
\hline Esmark's eelpout & Lycodes esmarki & A & - & - & - & - & - & + & ( ) \\
\hline Grenadier & Coryphaenoides rupestris & B & - & - & - & - & - & + & ( ) \\
\hline Smooth grenadier & Nezumia aequalis & MAB & - & - & - & - & + & ++ & ( ) \\
\hline Rough-nosed grenadier & Trachyrincus murrayi & B & - & - & - & - & - & + & ( ) \\
\hline Rat tail & Macrourus berglax & A & - & - & - & - & + & ++ & ( ) \\
\hline Golden redfish & Sebastes marinus & $\mathrm{AB}$ & + & + & ++ & ++ & ++ & ++ & ++ \\
\hline Deep-sea redfish & Sebastes mentella & $A B$ & + & ( ) & + & ++ & ++ & +++ & ++ \\
\hline Norway haddock & Sebastes viviparus & B & +++ & +++ & ++ & ++ & ++ & ++ & ++ \\
\hline Blue-throat & Helicolenus dactylopterus & MAB & - & ( ) & ++ & ++ & +++ & - & + \\
\hline Gray gurnard & Eutrigla gurnardus & MAB & + & ++ & ++ & ++ & + & ++ & ++ \\
\hline Threadfin sea snail & Rhodichthys regina & A & - & - & - & - & + & - & ( ) \\
\hline Deepwater cardinalfish & Epigonus telescopus & MAB & - & - & - & - & + & - & ( ) \\
\hline Horse mackerel & Trachurus trachurus & MAB & + & + & ( ) & - & - & - & + \\
\hline Catfish & Anarhichas lupus & B & + & + & + & - & - & - & + \\
\hline Greater sandeel & Hyperplus lanceolatus & B & - & ( ) & - & - & - & - & ( ) \\
\hline Sandeel & Ammodytes sp. & B & + & ++ & + & - & - & - & + \\
\hline Dragonet & Callionymus lyra & MAB & - & ( ) & - & - & - & - & ( ) \\
\hline Black scabbard fish & Aphanopus carbo & B & - & - & - & - & - & ++ & () \\
\hline Mackerel & Scomber scombrus & MAB & - & ( ) & ( ) & - & - & - & ( ) \\
\hline Turbot & Psetta maxima & MAB & - & ( ) & - & - & - & - & ( ) \\
\hline Megrim & Lepidorhombus whiffiagonus & B & - & ++ & + & ++ & - & ++ & + \\
\hline Whitch & Glyptocephalus cynoglossus & B & - & ( ) & - & - & - & ++ & () \\
\hline Long rough dab & Hippoglossoides platessoides & $\mathrm{AB}$ & + & + & - & - & - & ++ & + \\
\hline $\mathrm{Dab}$ & Limanda limanda & B & ++ & ++ & + & - & - & - & ++ \\
\hline Lemon sole & Microstomus kitt & B & ++ & ++ & + & - & - & - & ++ \\
\hline Plaice & Pleuronectes platessa & MAB & - & ( ) & - & - & - & - & ( ) \\
\hline Greenland halibut & Reinhardtius hippoglossoides & A & - & ( ) & - & - & - & ++ & ( ) \\
\hline Halibut & Hippoglossus hippoglossus & B & ++ & ++ & ++ & ++ & ++ & ++ & ++ \\
\hline Squid & Loligo forbesi & MAB, EA & +++ & ++ & ++ & +++ & ++ & - & ++ \\
\hline European flying squid & Todarodes sagittatus & MAB & ++ & ++ & ++ & ++ & + & ++ & ++ \\
\hline Number of species & & & 21 & 45 & 32 & 23 & 30 & 37 & 61 \\
\hline Number of trawl hauls & & & 24 & 178 & 44 & 17 & 21 & 19 & 303 \\
\hline
\end{tabular}


Bank area can be written as $S=7.42 A^{0.1975}, \mathrm{R}^{2}=0.75$. In a sampling program of a community, the number of collected species depends on sample size. Because of this, it is more realistic to compare the number of species collected in equal numbers of tows. Based on the first 17 tows at each depth zone, the equation works out to be $S=13.85 A^{0.0825}$. In this equation, the correlation coefficient $\mathrm{r}^{2}$ is only 0.17 , which means that only $17 \%$ of the number of species present can be explained by the size of the area. It is mainly for the depth zone from 100 to

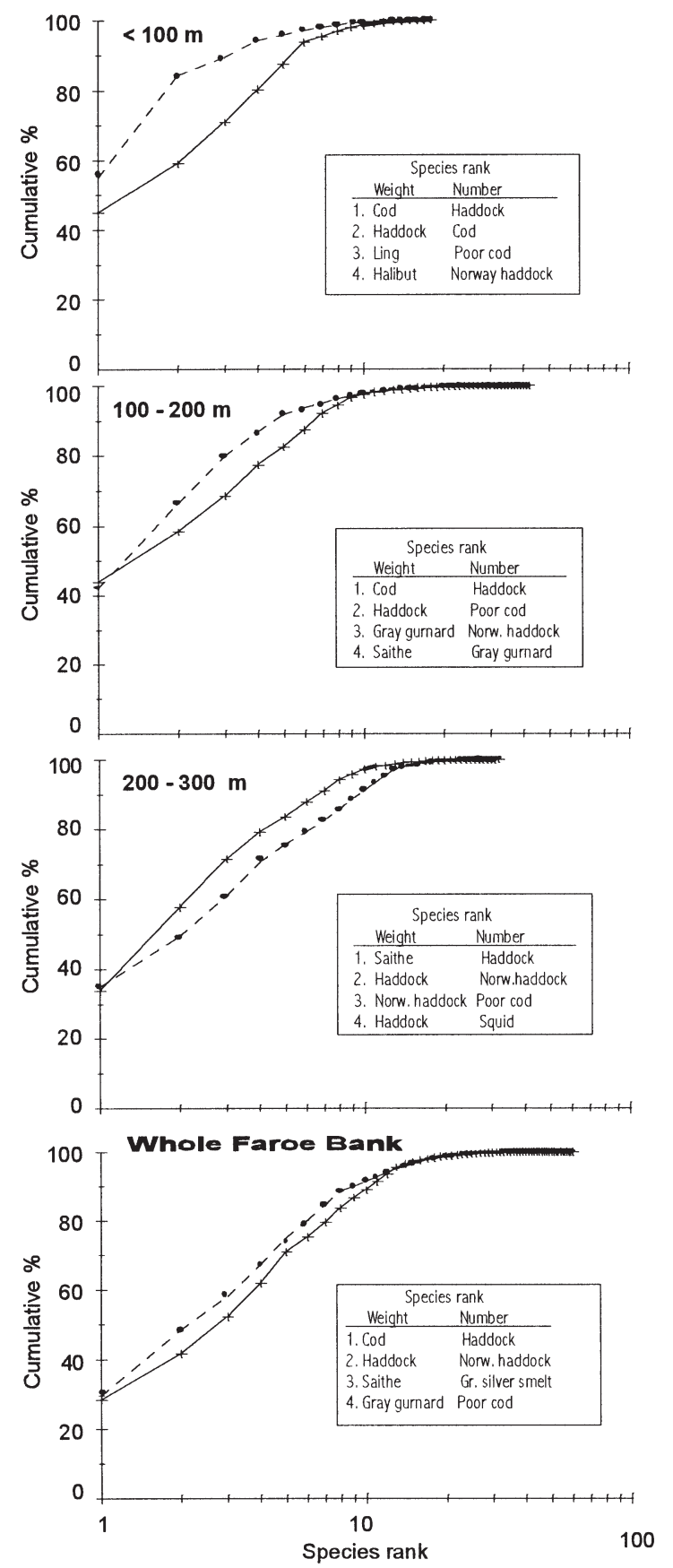

$200 \mathrm{~m}$ that the observed number of species (19) is lower than expected (27).

Although the total number of fish and squid species on Faroe Bank is relatively high, only a few species account for most of the fish abundance. The number of species in each of the 6 depth zones varies between 21 and 45 (Table 2), but of these, 4 of the most common species make up 61 to $88 \%$ of the total abundance and 67 to $94 \%$ of the total biomass (Fig. 4). Only a small number of the species are of commercial importance.

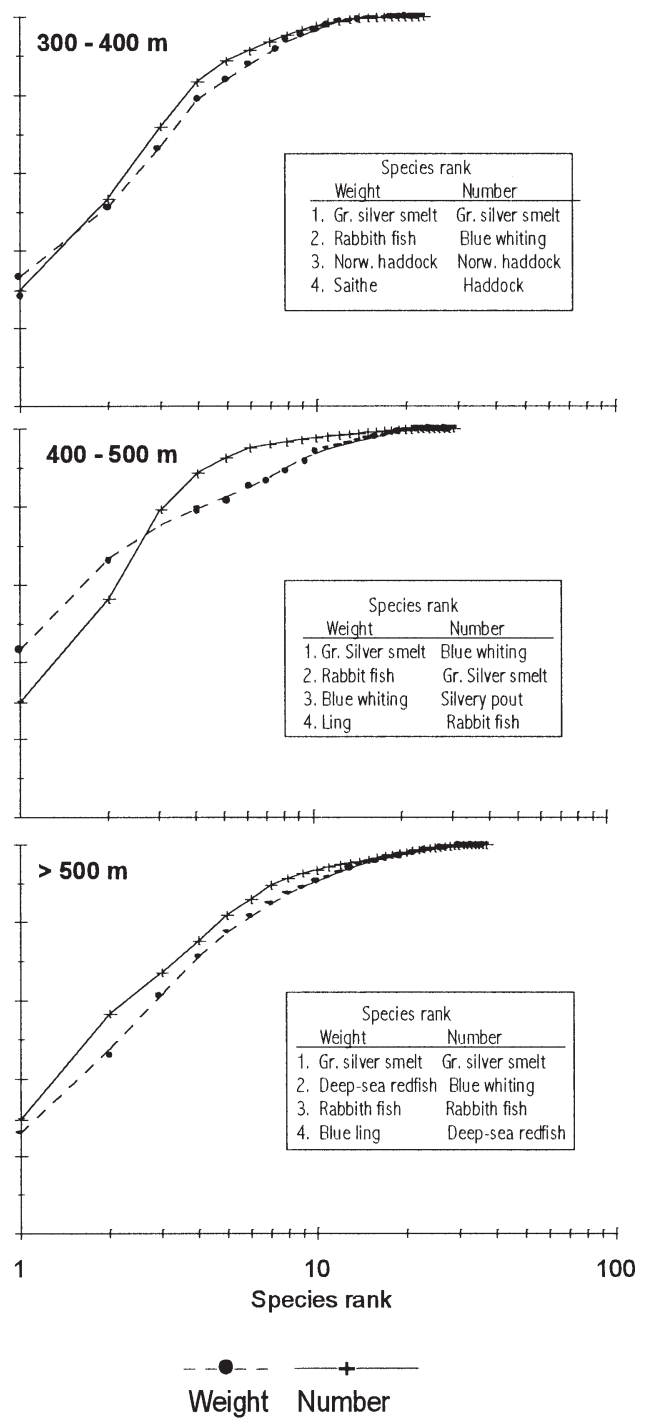

Fig. 4. K-dominance curves for each depth zone, based on weight and number of fish caught in bottom surveys on the Faroe Bank from 1983 to 1996. Species with the highest ranks are listed in the box 
The 12 species listed in Fig. 5 constitute $94 \%$ of the total annual catches, which on average has been on $11717 \mathrm{t} \mathrm{yr}^{-1}$ during the investigated period.

\section{Biomass spectra}

The size structure of each of the fish assemblages on Faroe Bank is shown in Fig. 6. Average body weight of fish decreases gradually with depth down to $500 \mathrm{~m}$ when it again increases. At depth shallower than 100 $\mathrm{m}$, average body weight of the fish was $5079 \mathrm{~g}\left(2^{12.31}\right)$ and in the depth zone 100 to $200 \mathrm{~m}$ it was $3708 \mathrm{~g}$ $\left(2^{11.36}\right)$. The dominant fish species here were cod and haddock, which make up 55 and $29 \%$ of the biomass at depths shallower than $100 \mathrm{~m}$ and 42 and $24 \%$ in the depth zone 100 to $200 \mathrm{~m}$, respectively (Fig. 4). The average size of cod was the same in both of this depth zones, namely, $81 \mathrm{~cm}$ and $6.4 \mathrm{~kg}$. Haddock size, on the other hand, decreased with depth. At depth shallower than $100 \mathrm{~m}$, the average size of haddock was $48 \mathrm{~cm}$ and $1000 \mathrm{~g}$ whereas it was $32 \mathrm{~cm}$ and $271 \mathrm{~g}$ in the depth zone of 100 to $200 \mathrm{~m}$. In deeper water other species become more predominant. In the depth zone of 400 to $500 \mathrm{~m}$, the biomass consist mainly of great silver smelt (43\%), rabbit fish (23\%) and blue whiting (9\%) (Fig. 4), which had the average size of $39 \mathrm{~cm}$ and $622 \mathrm{~g}$, $70 \mathrm{~cm}$ and $2700 \mathrm{~g}$ and $23 \mathrm{~cm}$ and $75 \mathrm{~g}$, respectively.

\section{Geographic distribution of the species}

The geographic distribution maps of the most common species on Faroe Bank are presented in Appendices 1, 2 \& 3 (www.int-res.com/journals/suppl/ magnussen_appendices.pdf). The highest departures from a homogeneous geographic distribution were found for blue whiting, Norway haddock, halibut and rabbit fish, which all were most common in Main Area B (Appendices $1 \& 2$ ), but none of the test values was significant ( $p=0.059$ to 0.065$)$. For 3 of the species, there was a significant difference in the frequency of occurrence between the south and north areas $(p<0.05)$ : Norway haddock and halibut were most common in the southern area whereas haddock was most common in the northern area (Appendix 1). Testing the eastwest component in the distribution, significant differences ( $p<0.01$ ) were found for 3 of the species: blue whiting, silvery pout and rabbit fish were all most common on the west side of Faroe Bank (Appendices 2 \& 3).

\section{Fish assemblages}

Based on cluster analyses, the fish fauna on the Faroe Bank falls into 3 assemblages: a shallow, a deeper and an intermediate assemblage in-between (Fig. 7). The shallow assemblage is geographically located on the middle of the bank bounded by the $200 \mathrm{~m}$ depth contour. Most of this assemblage is in the Main Area A. The shallow assemblage is split up into 2 sub-groups: One in the northeastern part of the area consisting mainly of cod, and another group in the southwestern part represented by the remaining species. For the intermediate and deep assemblages, no systematic pattern in geographic distribution was found.

\section{Preferred depth}

The parameter explaining most of the spatial distribution of the fish assemblages on Faroe Bank is depth (Fig. 8) and the depth range is fairly consistent with results from the cluster analysis (Fig. 7).
Fig. 5. Mean + SE of annual commercial landings of fish caught on Faroe Bank from 1983 to 1996

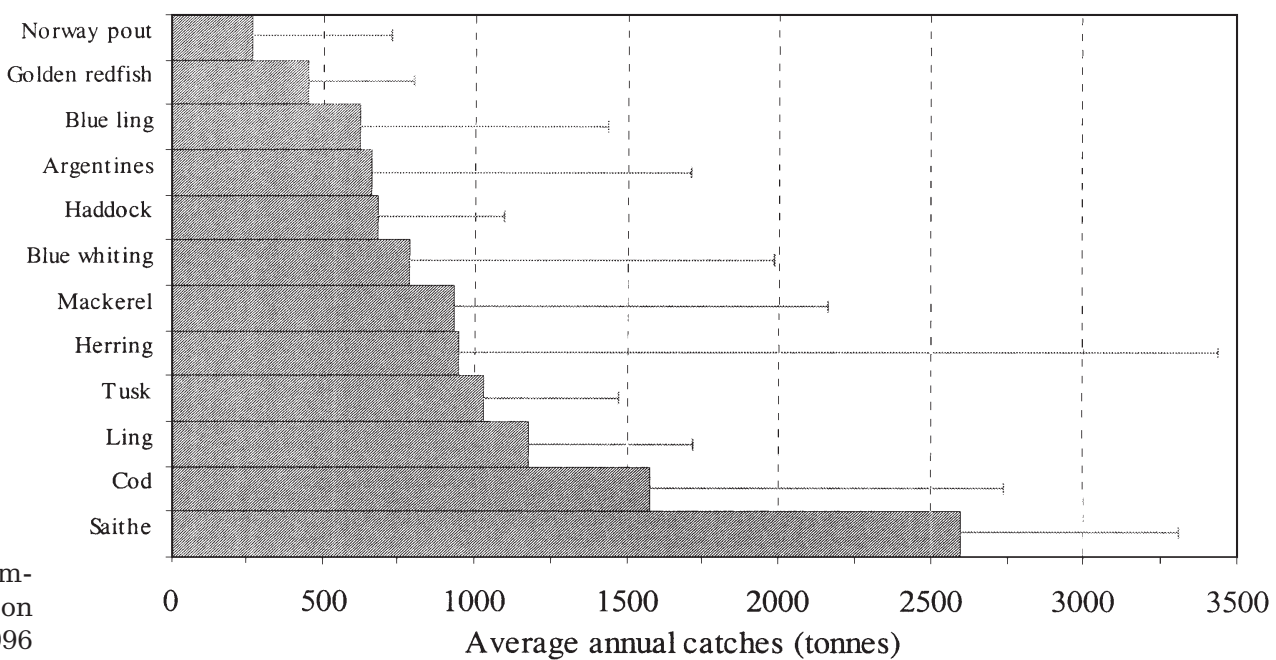




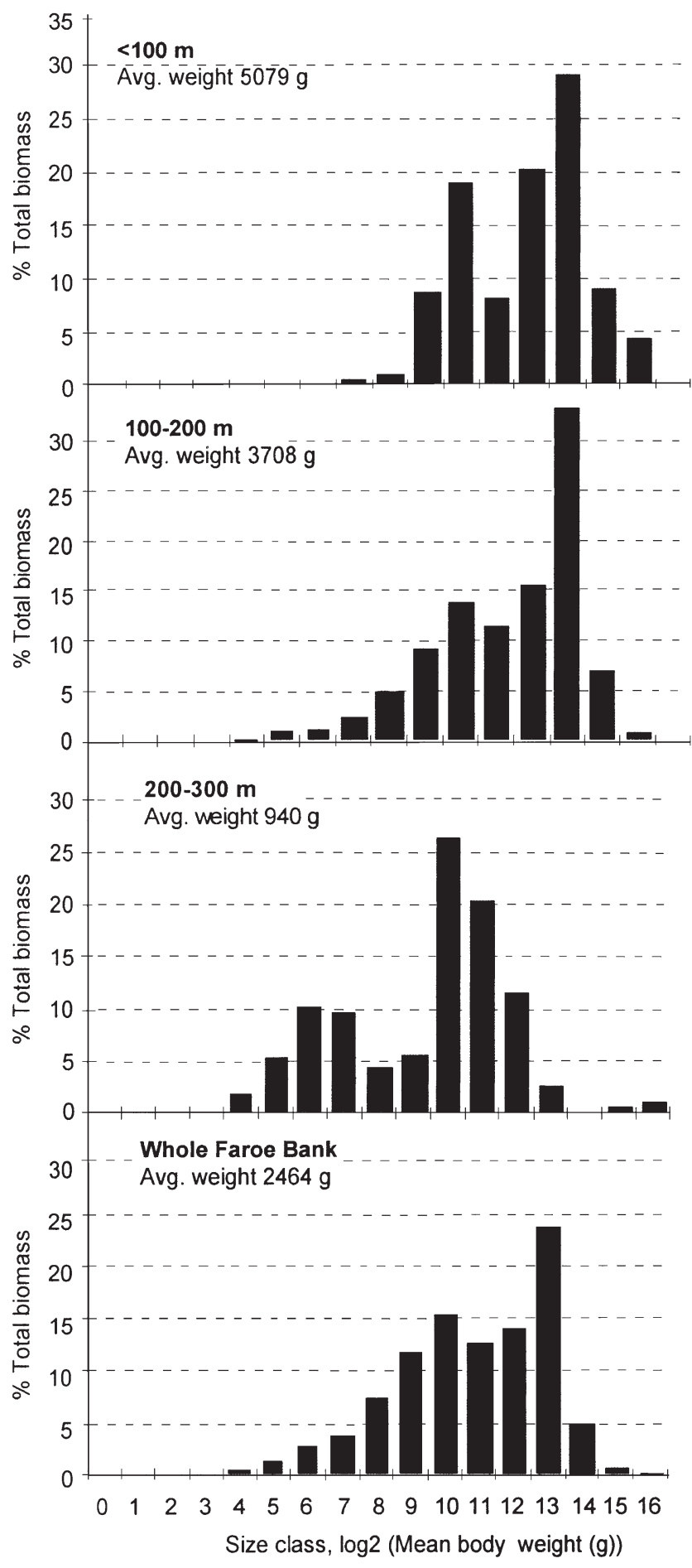

From these results, the shallow, intermediate and deep fish assemblages on the Faroe Bank could be defined as fish living in the depth range between 120 and $210 \mathrm{~m}, 210 \mathrm{~m}$ and $430 \mathrm{~m}$, and 430 and $680 \mathrm{~m}$, respectively. For the intermediate assemblage, the preferred depth is not so well defined as for the 2 other assemblages. From above, the intermediate fauna is

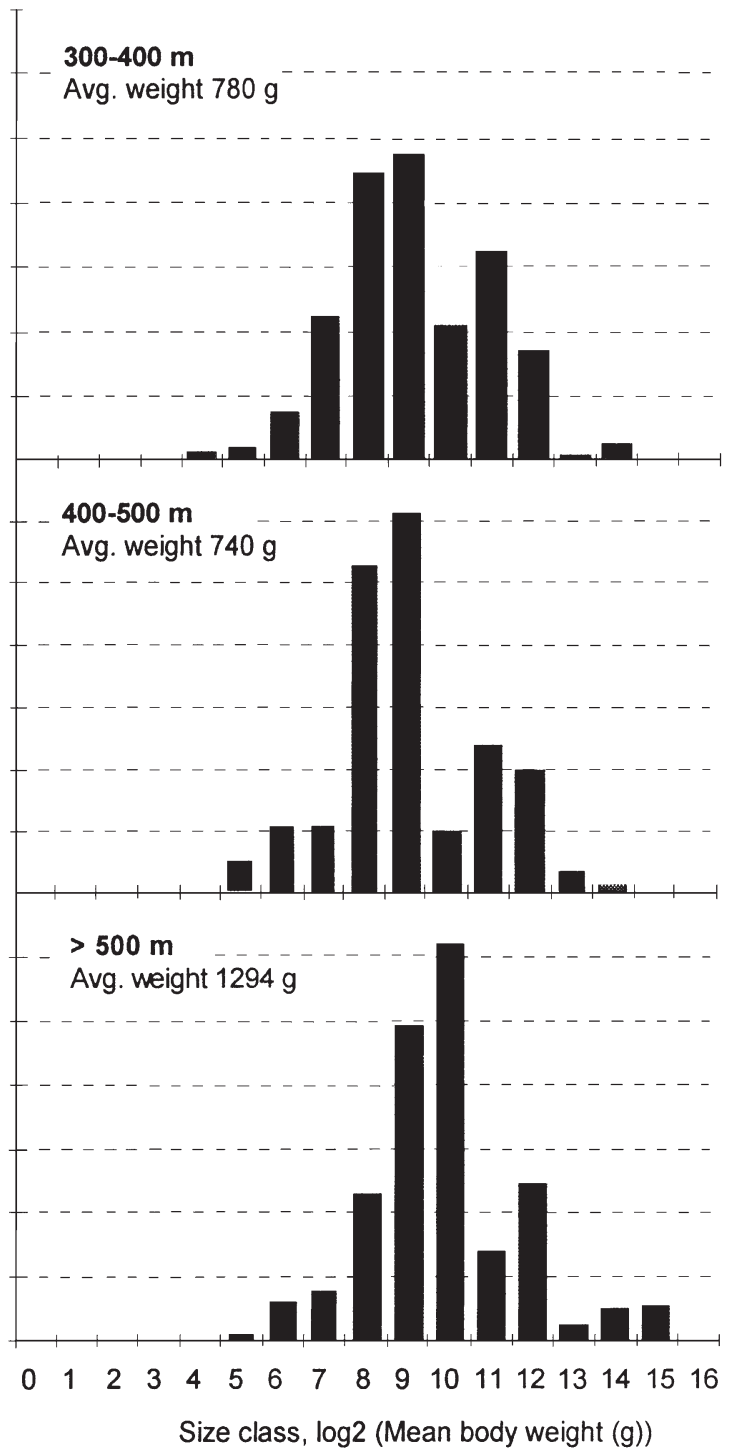

Fig. 6. Biomass spectra for different depth zones of the demersal fish assemblages on Faroe Bank. The size classes correspond to the $\log _{2}$ of weight (numbers indicate the lower boundary of each class)

overlapped by Norway haddock and golden redfish, which have average depth ranges of 274 and $348 \mathrm{~m}$, respectively. While megrim and anglerfish overlap from below and have average depths ranges of 290 and $295 \mathrm{~m}$, respectively. They are also the 2 species with the highest SD with depth. Neither silvery pout nor spur-dog fit these depth classifications well. 


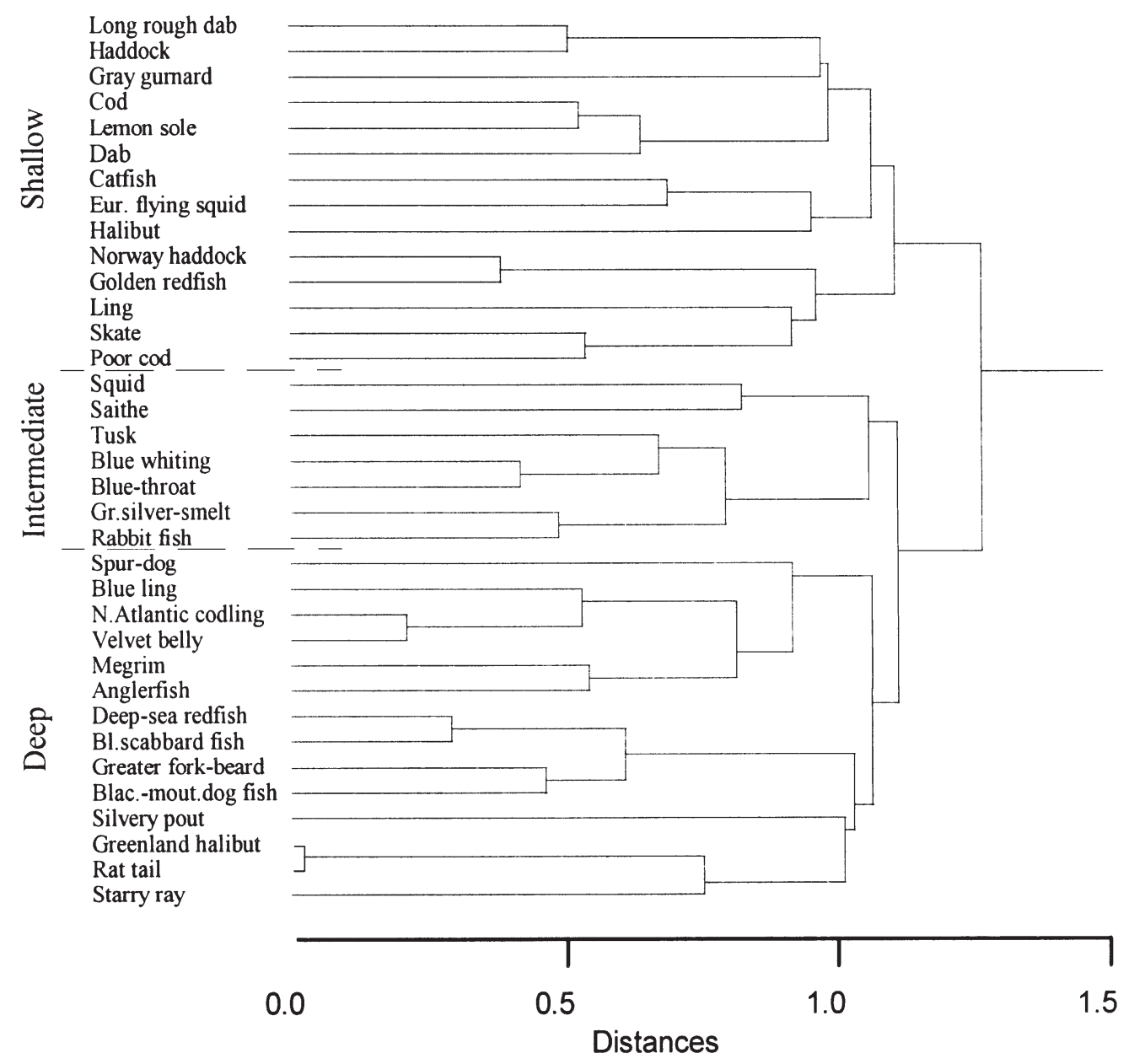

Fig. 7. Cluster analysis of the fish fauna on Faroe Bank

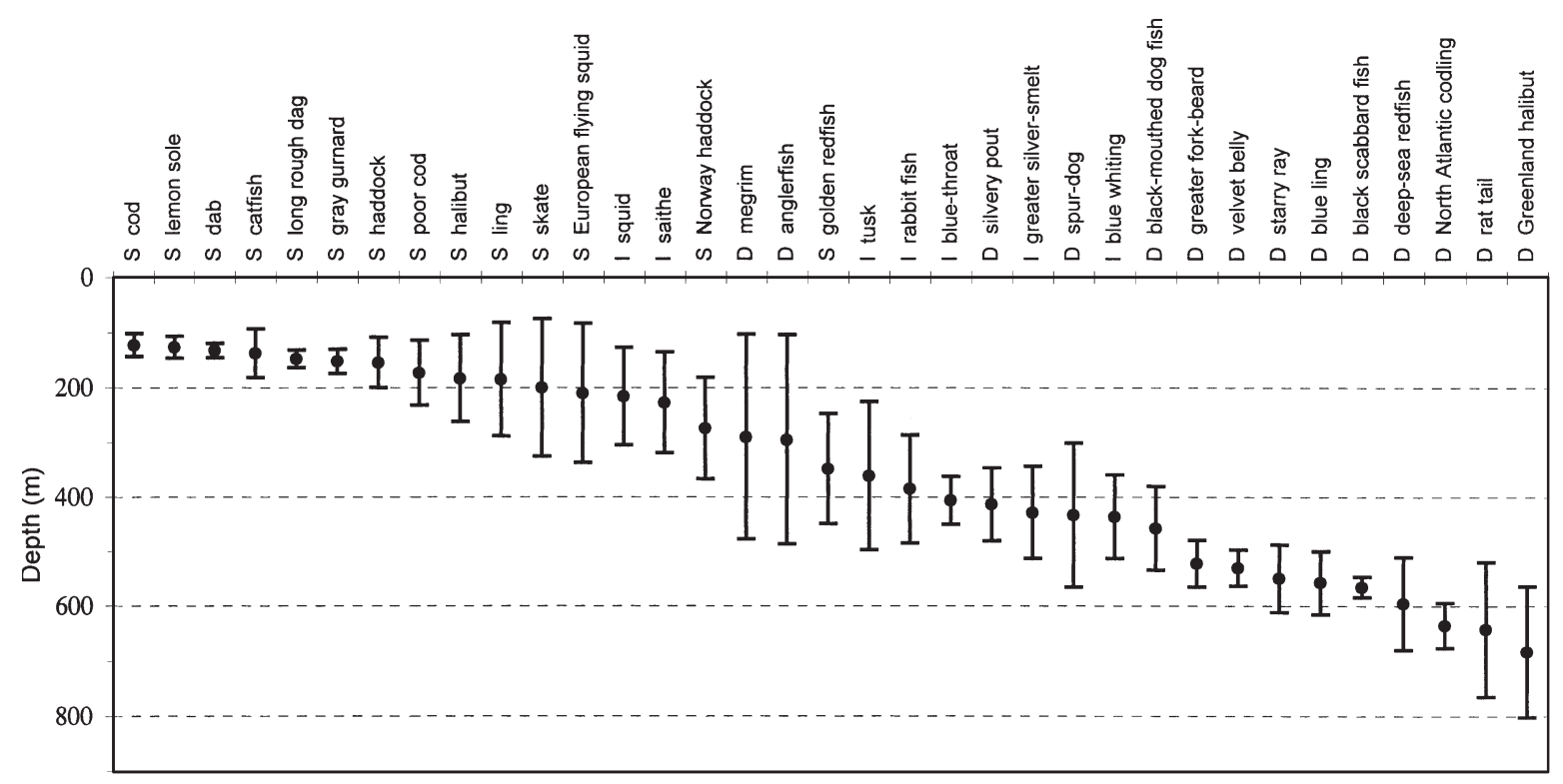

8. Preferred depth for demersal fish on Faroe Bank. Weighted average depth \pm SD. S refers to species of belonging the shallow fauna, I of the intermediate fauna and D of the deep fauna 

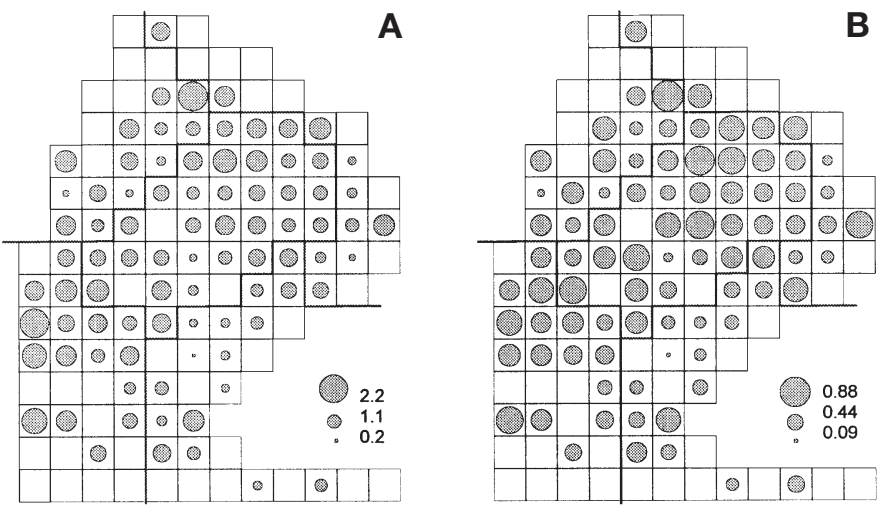

Fig. 9. Geographic pattern of Shannon species diversity (A) and evenness (B) indices for the demersal fish fauna on Faroe Bank

\section{Species diversity and evenness}

The average Shannon species diversity index per square varies between 0.177 and 2.104 (Fig. 9). Even with this high range, the difference in diversity indices among the 5 main areas was significant $(p=0.042)$. The highest species diversity was found toward the southwest side of Faroe Bank (Main Area B: median = 1.295) and the lowest in the southeast (main Area E: median $=0.989$ ).

For the southern main area (Main Areas B and E) the median of diversity indices was 1.161 compared to 1.108 for the northern area (Main Areas C and D) but this difference was not significant $(p=0.717)$. For eastern and western area (Main Areas D and E against Areas B and C) there was a significant difference between the diversity values $(p=0.007)$. For the western side, the median was 1.261 and for the eastern side it was 1.035. Discriminating among assemblages, the highest species diversity was found for the deep assemblages (median $=1.492$ ) while for the intermediate and shallow assemblages it was 1.099 and 1.173, respectively; however, these differences were not significant ( $p=0$.185). Based on linear regression, a significant relationship was found between the Shannon index and depth in Main Areas B and C. For Main Area $\mathrm{B}$, the linear equation was: Shannon $=0.001276 \times$ $($ Depth $)+0.9850,\left(r^{2}=0.23, p=0.001\right)$, and for Main Area C: Shannon $=0.001404 \times($ Depth $)+0.7536,\left(r^{2}=\right.$ $0.17, p=0.023)$. For the other main areas, no significant relationship between diversity-index and depth could be detected.

In the evenness index, there were also significant differences between the main areas $(p=0.043)$. Evenness was highest on the central bank (Main Area A: median $=0.61)$; however, the other areas did not differ from each other. The lowest evenness was found in the southeast area (Main Area E: median = 0.47). Comparing the southern area against northern and eastern area against western, no significant differences were found in evenness indices between these areas. Only in 1 area (Main Area A), did evenness change with depth. Here, the lowest values were found on the deep stations. The linear equation for this line is: Evenness $=$ $-0.00249 \times($ Depth $)+0.9118,\left(\mathrm{r}^{2}=0.11, \mathrm{p}<0.001\right)$. There were no significant differences in evenness indices among the shallow, intermediate and deep assemblages ( $p=0.197$ ), which had median of 0.59 , 0.50 and 0.61 , respectively. Using clustering techniques no systematic pattern could be identified, neither in species diversity nor evenness.

\section{DISCUSSION}

\section{Catches}

Due to the small size of Faroe Bank the total catch of fish is relatively small compared to other ecosystems (Fig. 5). The average annual commercial catch on the bank during the period from 1983 to 1996 was 11717 t. The commercially most important fish species were saithe, cod, ling and tusk. On average, $56 \%$ of the total catches were made up of these key species. However, in some years, the pelagic species blue whiting, herring and mackerel have been present in significant numbers and induced big fluctuations in the total catches. Thus, in 1995 and 1996, these 3 species made up 40 and $47 \%$ of the total catches, respectively.

\section{Species richness}

The area studied is limited in size and depth range and hence well suited for study. However, the complex hydrography makes direct comparison to other areas difficult. In total, 61 fish species have been caught in the bottom trawl surveys, most of these were demersal (Table 2). The main reason for the low proportion of pelagic species in the survey is that they naturally occur in low numbers on Faroe Bank. Additionally, the survey was designed to sample demersal species. Taking into account the small size of Faroe Bank, it supports relatively many demersal fish species.

On Grand Bank between 29 and 34 species comprised $99.9 \%$ of the total catches each year in the spring surveys from 1971 to 1987 (Gomes et al. 1992). In bottom trawl surveys on the Newfoundland continental slope, 39 demersal fish species were reported in the depth range from 204 to $2325 \mathrm{~m}$ (Snelgrove \& Haedrich 1985). On the Rockall Trough, 66 species were reported at depths from 245 to 2975 m (Gordon \& 
Bergstad 1992) and on the slope of the eastern Norwegian Sea, 34 fish species were caught at depths from 430 to 2050 m depth (Bergstad et al. 1999). Compared to neighbouring areas, Iceland has a total of 231 fish species (Jónson 1983) and Greenland has 216 (Nielsen et al. 1992). In fish assemblages, species are not represented equally. Although the Barents Sea has around 140 species of fish, only about 10 of these are very abundant (Livingston \& Tjelmeland 2000). In the North Sea, 87 species were caught in English bottom surveys between 1977 and 1986 (Daan et al. 1990); however, this is only a fraction of the total number of fish species in the North Sea, where, according to Knijn et al. (1998), a total of 224 species have been recorded.

The fish fauna on Faroe Bank is similar to that of the North Sea, but there are also differences. Of 63 fish species or species-groups caught in bottom surveys in the northern North Sea from 1977 to 1979, Pope \& Knights (1982) had already found 32 of these species in a bottom survey on Faroe Bank in 1971. Of all species found on Faroe Bank only 1, the spotted catfish Anarhichas minor, was not found in the northern North Sea. Compared to other neighbouring areas, 23 of 66 fish species on the Rockall Trough (Gordon \& Bergasta 1992) and 17 of 34 species on the slope of the eastern Norwegian Sea (Bergstad et al. 1999) were also found on Faroe Bank. In the descriptions of the fish assemblages mentioned above, different fishing gear, depth of fishing and sampling intensities have been used; therefore, results may not be completely comparable.

\section{Change in species composition}

A change in species composition seems to have occurred on Faroe Bank during the last decades. In their description of 'Marine and freshwater fishes' of the Faroe Islands, Joensen \& Tåning (1970) described 148 fish species living around the Faroes of which they found only 31 fish species recorded by research ships within the $200 \mathrm{~m}$ contour on Faroe Bank. Of these, 8 species were not found in the present bottom surveys (Argentina sphyraena, Boreogadus esmarki [synonym Trisopterus esmarki], Molva elongata, Onos sp., Gobius sp., Chirolophis galerita, Cottus sp. and Triglops pingeli). In a bottom survey comprising 32 trawl stations with 2 replicates, Jones \& Pope (1973) caught 38 species within the $366 \mathrm{~m}$ depth contour. Of these, 7 species were not found in the present survey (Trisopterus esmarki, Anarichas minor, Triglops sp., Lycenchelys sp., Centrophorus squamosus, Raja naevus and Petromyzon marinus). Of those species listed above not found in the bottom trawl surveys between 1983 and 1996, Trisopterus esmarki was found in later surveys. The absence of the other species indicates that their distributional range has shifted. This shift may have been minor, since 4 of the species (Argentina sphyraena, Molva elongata, Gobius sp. and Raja naevus) had, according to Joensen \& Tåning (1970), their northwesterly boundary at the Faroes. In the present study, 43 fish species were described within the $200 \mathrm{~m}$ depth countour, compared to 31 species in Joensen \& Tåning (1970) in the same depth range. Differences in sampling make it difficult to connect the finding of these 12 new species to possible changes in the Faroe Bank ecosystem during this period. However, most of the new species are not common. Thus, they can in most cases probably be related to the higher sampling intensity in the present study; however, 2 of the species, namely Trisopterus minutus and Molva molva, which are common in this study, are not in the former list of species on Faroe Bank. This must be a mistake, because in the text (p 102 and 116) they are mentioned to be common on the bank. Joensen \& Tåning (1970) did not mention Argentina silus and Chimaera monstrosa as part of the Faroe Bank fish fauna, but in the present study they were caught in 6.4 and $5.9 \%$, respectively, of the 202 tows shallower than $200 \mathrm{~m}$. Todarodes sagittatus was not caught in Jones \& Pope's (1973) investigation, but in the present study, they were caught in $28 \%$ of the 259 tows shallower than $366 \mathrm{~m}$.

\section{Species-area relationship}

In this paper, the species-area relationship has been introduced to marine fish species community (Fig. 3). Species richness in an ecosystem depends on many factors. One factor is size of the ecosystem. Larger ecosystems normally have more species. Area in itself may not be the primary factor affecting species diversity in most situations, but it presumably operates indirectly by increasing the variety of available habitats. For Faroe Bank, only $17 \%$ of its species richness could be explained by size of the area alone. The area dependence of species richness in an ecosystem can be expressed by the $Z$-value in the island biogeography equation (Pianka 1988). For the Faroe Bank area, the $Z$-value in the species-area equation was 0.1975 when calculations were based on all tows and 0.0825 when based on the first 17 tows in each depth zone. No references have been found on $Z$-values for marine fish communities, but for various mainland terrestrial ecosystems the $Z$-value generally ranges from 0.12 to 0.17 (Pianka 1988). In freshwater communities, the $Z$-value of fish in rivers is generally in the order of 0.24 to 0.55 and for lakes 0.15 to 0.35 (Wootton 1990). 


\section{Biomass spectra}

A useful tool to describe fish communities is the analysis of size spectra (Fig. 6). This method is based on how individuals are distributed among size classes, irrespective of species identity. The fish assemblages on Faroe Bank are characterised by large fish. On the shallowest part of the bank, the average size was $5079 \mathrm{~g}\left(2^{12.31}\right)$ and as we descended deeper, the average size of fish decreased. This is a consequence of replacement of the dominant large and mediumsized cod and haddock by smaller species (Fig. 4). A 'smaller-deeper' trend has also been demonstrated in other fish assemblages (Stefanescu et al. 1992), but this size reduction is not a rule and the opposite has also been seen (Marrett \& Haedrich 1997). For the biomass spectra, both shape and location is depth-dependent. For fish assemblages in the Benguela system off Namibia, Macpherson \& Gordoa (1996) found the biomass spectrum to be related to productivity in the area. In the most productive area, the abundance of the smallest size classes was extremely high and clearly decreased in the bigger size classes, whereas in less productive areas the biomass tended to increase, or at least remain constant over the size spectrum.

Comparing biomass spectra is rather difficult, because often different methods and analyses have been used. Marrett \& Haedrich (1997) presented biomass spectra for the deep fish assemblages on the Newfoundland Shelf in the same way as done here. They found that in 1981 the size class $2^{11}$ (2048 g) was dominating but species and size composition in 1991 shifted the peak to a smaller size class of fish $\left(2^{9}, 512 \mathrm{~g}\right)$. Another way to analyse biomass spectra is to compare the slope of the line resulting from plotting log numbers of fish against fish size. Pope \& Knights (1982a) did this for Faroe Bank and the North Sea. They found the slope of the size spectrum for the North Sea to be steeper than on Faroe Bank. In the North Sea, $50 \%$ of the fish were smaller than $30 \mathrm{~cm}$ while the corresponding length for Faroe Bank was $70 \mathrm{~cm}$. Possible explanations are the high growth rates of fish which have been established for some species (Ursin 1984) and the lower fishing intensity on Faroe Bank (Jones 1962). When modelling size spectra of fish assemblages, Gislason \& Rice (1996) found that the slope decreased when the fish grew faster, whereas an increase in fishing intensity resulted in a steeper slope. On Faroe Bank, 13 of 14 species investigated had intermediate or accelerated growth rates (Magnussen unpubl.). Although catch statistics have been established for Faroe Bank (Fig. 5), no stock assessment has been performed for the area. Because of this, no figures on fishing mortality $(F)$ are available; however, it is my impression that it is low compared to other areas such as the North Sea (Cook et al. 2000).
Biogeography on the bank

The complex hydrographic situation with both warm and cold water masses joining on either side of Faroe Bank does not seem to have any major influence on the biogeography of the demersal fish assemblages on the bank. The fish assemblages are mainly boreal, but the occurrence of Arctic as well as Mediterranean species bears witness to the composite nature of the area. Although Faroe Bank is a small area, the seabed conditions are not homogeneous (Fig. 1). This may influence the geographic distribution of the fish species, some of which are more common in some areas and are in some cases restricted to a limited area of the bank. Only 6 species show significant differences in the geographic distribution patterns between areas. This was most evident for silvery pout, which was restricted to the western side of the Faroe Bank (Appendix 3; www.int-res.com/journals/suppl/magnussen_ appendices.pdf), a change in distribution pattern compared to the findings by Jones \& Pope (1973). They found the highest abundance in the same area as reported here, but they also found small concentrations of silvery pout on the eastern side of the bank, which was not found in present study. Additionally, the frequency of occurrence for blue whiting and rabbitfish was higher on the western side of the bank (Appendix 2). Norway haddock and halibut preferred the southern part of the bank whereas haddock was more common in the northern area (Appendix 2). In defining fish assemblages, hydrographic factors are important, but these factors do not seem to explain why some species are more common or restricted to specific areas of Faroe Bank. Neither could these distribution patterns be related to specific zoogeographical groupings. The inhomogeneous distribution in geographic patterns for some of the species are therefore probably related to seabed conditions, but hydrographic conditions and depth may also be important.

\section{Fish assemblages}

As found in similar studies (Gomes et al. 1995), depth was consistently associated with a significant proportion of the variation of the fish on Faroe Bank. Three fish assemblages were distinguished (Fig. 7), each closely associated to bottom depth. Only the shallow fish assemblages could further be subdivided into a northern and a southern sub-group. For the other fish assemblages, there were no unambiguous patterns in geographic distributions. In other areas, e.g. Denmark Strait and Irminger Sea (Haedrich \& Krefft 1978) and on the slope of the eastern Norwegian Sea (Bergstad et al. 1999), separate fish assemblages were identified, 
each characterised by specific depth, temperature and species composition. On Faroe Bank, the identification of assemblages was not always so clear. The structure of the cluster was not always so well defined and has relative many intermediate-scale linkages, indicating more gradual changes in species composition. This was also confirmed by the preferred depth for the fish species (Fig. 8), which shows a shallow and a deep assemblage, each with relatively modest variance in depth distribution, and an intermediate assemblage of species with broad and overlapping depth ranges. This pattern is probably explained by the homogeneous hydrographical conditions on the bank. The boundaries of fish assemblages may shift as environmental conditions change. This has been seen e.g. on the northeast Newfoundland/Labrador Shelf (Gomes et al. 1995). On the southern and southeastern parts of the Faroe Bank, cold water of Faroe Shetland Channel deep overflow sometimes penetrates this area (Ellett 1998). This penetration is temporary and spatially heterogeneous. It may also influence the composition of the fauna living on the bottom in these areas. Greenland halibut, which is a cold water species, was caught here. Because the aim of the present study was to give an overview of the fish assemblages on Faroe Bank, analyses are based on average values for the period from 1983 to 1996 from February to May. Therefore, possible spatial and temporal variability are not apparent.

\section{Preferred depth}

As shown in the cluster analysis, no distinct communities could be found for the fish fauna on Faroe Bank.. Most of the species on the bank have a narrow depth range (Fig. 8). Scott (1982) described depth preferences for fish living on the Scotian Shelf. Ten of these species also occur on Faroe Bank, and a comparison shows that all species prefer a greater depth at Faroe Bank; $_{i}$ the species depth successions are similar, except for spur-dog, starry ray and Greenland halibut which have preferred depths of 433, 549 and $683 \mathrm{~m}$ on Faroe Bank compared to 144, 105 and $217 \mathrm{~m}$ on the Scotian Shelf. For most fish species, depth range increases as the fish grow (Macpherson \& Duarte 1985, Swain 1993, Hanson 1996, Uiblein et al. 1996). Because of this, geographic distribution patterns also will change as the fish grow, but this factor has not been taken into account in the present analysis.

\section{Species diversity}

The species diversity index for the demersal fish fauna is low on Faroe Bank compared to other areas
(Fig. 9A). The median of the Shannon index for the fish assemblages on Faroe Bank is 1.165. For the English inshore demersal fish assemblages, Rogers \& Millner (1996) found the Shannon diversity index to range between 1.58 and 1.93. For the fish assemblage off Newfoundland, Snelgrove \& Haedrich (1985) found the Shannon index to be 1.5, for both depth ranges of 200 to $1475 \mathrm{~m}$ and 1712 to $2335 \mathrm{~m}$. In the Denmark Strait and Irminger Sea, Headrich \& Krefft (1978) found species diversity to be in the range of 1.6 to 2.1. Because the Shannon species diversity index is sampling-dependent, comparison between investigations is not straightforward. The results will be influenced by type of gear used and tow duration; moreover it will also depend on whether the calculations are based on individual hauls or pooled data.

On Faroe Bank, the highest species diversity was found in Main Area B, which has the most gradual slope, more heterogeneous bottom conditions and hence more species. This area has an influx of nutrient-rich water masses (Gaard et al. 1993), which facilitate primary production. Increased productivity leads to higher species diversity (Begon et al. 1996). The lowest species diversity was found in Main Area $E_{i}$ this area has a steep slope and a uniform seabed. This, together with the hydrographic conditions with cold water on greater depths, may be a reason for the low species diversity in this area. The median for the evenness index was 0.581 for the whole of Faroe Bank (Fig. 9B). This is in the same order of magnitude as has been found for other similar ecosystem. For the Denmark Strait and Irminger Sea, Haedrich \& Krefft (1978) found evenness to vary between 0.49 and 0.78 and for the English inshore demersal fish assemblages it was between 0.47 and 0.51 (Rogers \& Millner 1996).

Species diversity increased with depth in 2 of the main areas (B and C) on the Faroe Bank whereas the evenness index declined with depth in 1 of the main areas (A). A change in species diversity and evenness indices by depth is common in marine ecology (Gage \& Tyler 1991). For the fish assemblages off Newfoundland, Snelgrove \& Haedrich (1985) found evenness to be 0.4 in the depth range of 200 to $1475 \mathrm{~m}$ and 0.7 in the depth range of 1712 to $2335 \mathrm{~m}$. In the fish assemblages Southeast of New Zealand, McClathchie et al. (1997) found species richness and Shannon species diversity and evenness to increase with depth.

In a community, species diversity can also be described using a rank-abundance plot (Magurran 1988). When plotting the most abundant species first, then the next commonest and so on, for each of the 6 depth zones, the plot for the shallowest depth has the most geometric shape. As the depth increases, the shape of the lines fits better with the broken stick model. In a rank-abundance plot, fitting the geometric series, there 
are few dominant and many rare species while the broken stick model is characterised by a more equal abundance of species. Based on this, a community where the broken stick model applies has a higher evenness index than if the geometric series is the best fit (Magurran 1988). This also seems partly to be true for the Faroe Bank fish assemblages, where the highest evenness index (0.61) was found in the shallowest area (Main Area A).

The present study has shown that although Faroe Bank is a small area, its species richness is high, but only a few species make up most of the abundance and biomass. The fish assemblages on Faroe Bank are mainly boreal. During the last decades, some fish species have disappeared from the bank, whereas new ones have immigrated. The fish species are not evenly distributed, neither horizontally nor vertically. Additionally, the complex hydrographic conditions with mixed water masses on the slope of the bank have no major influence on the biogeography of the demersal fish assemblages, where the water masses are relatively homogeneous. Species diversity for the demersal fish assemblages is low on Faroe Bank as compared to other areas.

Acknowledgements. I thank my colleagues for support in practical work and Professor Dr. A. Nørrevang and Dr. E. Gaard for critical reading of former versions of the manuscript. I am especially grateful to Professor Henrik Gislason, Danish Institute for Fisheries and Marine Research and Dr. J. Rice for a lot of good advice and critical reading of the manuscript.

\section{LITERATURE CITED}

Begon M, Harper JL, Townsend CR (1996) Ecology. Blackwell Scientific Publications, Oxford

Bergstad OA, Bjelland O, Goyke AP (1999) Fish communities on the slope of eastern Norwegian Sea. Sarsia 84:67-78

Cook RM, Sinclair A, Stefansson G (2000) Potential collapse of North Sea cod stocks. Nature 385:521-522

Coull KA, Jermyn AS, Newton AW, Henderson GI, Hall WB (1989) Length/weight relationships for 88 species of fish encountered in the North East Atlantic. Scottish Fisheries Research Report, No. 43. Department of Agriculture and Fisheries for Scotland, Aberdeen, p 1-79

Daan N, Bromley PJ, Hislop JRG, Nielsen NA (1990) Ecology of North Sea fish. Neth J Sea Res 26:343-346

Dahle G (1995) Genetic structure of the North-East Atlantic cod (Gadus morhua L.), an appraisal of different molecular techniques. University of Bergen, Department of Fisheries and Marine Biology

Ellett (1998) Norwegian Sea deep water overflow across the Wyville-Thomson Ridge during 1987-88. In: Hansen B, Østerhus S (eds) North Atlantic-Norwegian Sea exchanges: The ICES NANSEN Project, No. 225. ICES, Copenhagen, p 195-205

Fjallstein I, Magnussen E (1996) Growth of Atlantic cod (Gadus morhua L.) of Faroe Bank strain and Faroe Plateau strain in captivity. ICES-CM F:1-16

Frederiksen R, Jensen A, Westerberg H (1992) The distribu- tion of the scleractinian coral Lophelia pertusa around the Faroe Islands and the relation to internal tidal mixing. Sarsia 77:157-171

Gaard E, Mortensen H (1993) Phyto- and zooplankton communities on the Faroe Bank and their relations to the physical and chemical environment. ICES-CM L:1-17

Gage JD, Tyler PA (1991) Deep sea biology — a natural history of organisms at the deep-sea floor. Cambridge Univ Press, Cambridge

Gislason H, Helgason T (1985) Species interaction in assessment of fish stocks with special application to the North Sea. Dana 5:1-44

Gislason H, Rice J (1996) Modelling the effect of changes in fishing effort on the size and diversity spectra of exploited fish assemblages. ICES CM Mini:1-7

Gomes MC, Haedrich RL, Rice J (1992) Biogeography of groundfish assemblages on the Grand Bank. J Northwest Atl Fish Sci 14:13-27

Gomes MC, Haedrich RL, Villagareia MG (1995) Spatial and temporal changes in the groundfish assemblages on the north-east Newfoundland/Labrador Shelf, north-west Atlantic, 1978-1991. Fish Oceanogr 4:85-101

Gordon JDM, Bergstad OA (1992) Species composition of demersal fish in the Rockall Trough, North-Eastern Atlantic, as determined by different trawls. J Mar Biol Assoc 72: 213-230

Greenstreet SPR, Hall SJ (1996) Fishing and the ground-fish assemblage structure in the north-western North Sea: An analysis of long-term and spatial trend. J Anim Ecol 65: $577-598$

Haedrich RL, Krefft G (1978) Distribution of bottom fishes in the Denmark Strait and Irminger Sea. Deep-Sea Res 25: $705-720$

Hall SJ (1999) The effects of fishing on marine ecosystems and communities. Blackwell, Oxford

Hansen B (1985) The circulation of the northern part of the Northeast Atlantic. Rit Fiskideildar 9:110-126

Hansen B, Kristiansen R (1999) Variation of the Faroe Bank Channel overflow. Rit Fiskideildar 16:13-22

Hansen B, Østerhus S (2000) North Atlantic - Nordic Seas Exchanges. Prog Oceanogr 45:109-208

Hansen B, Meldrum D, Ellett D (1991) Satellite-tracked drogue paths over Faroe Bank and the Faroe-Iceland Ridge. ICES CM C:1-14

Hanson JM (1996) Seasonal distribution of juvenile Atlantic cod in the southern Gulf of St Lawrence. J Fish Biol 49: $1138-1152$

Jennings S, Kaiser MJ (1998) The effects of fishing on marine ecosystems. Adv Mar Biol 34:201-352

Joensen H, Steingrund P, Fjallstein I, Grahl-Nielsen O (2000) Discrimination between two reared stocks of cod (Gadus morhua) from the Faroe Islands by chemometry of fatty acid composition in the heart tissue. Mar Biol 136:573-580

Joensen JS (1956) Tagging experiments of cod West of Suduroy in 1952 (Merking av toski vestan fyri Suðuroy í 1952). Fróðskaparrit 5:25-97

Joensen JS, Tåning ̊̊V (1970) Marine and freshwater fishes. In: Spærck R, Tuxen SL (eds) The zoology of the Faroes, Book 3. Høst, Copenhagen

Jones BW (1966) The cod and the cod fishery at Faroe. Her Majesty's Stationary Office, London

Jones BW, Pope JG (1973) A groundfish survey of Faroe Bank. ICNAF Research Bulletin 10:53-61

Jones R (1962) Haddock bionomic. II. The growth of haddock in the North Sea and at Faroe. Mar Res 2:1-19

Jónson G (1983) Icelandic fishes (Íslenskir fiskar) (in Icelandic). Fjølvaútgáfan, Reykjavík 
Knijn RJ, Boon TW, Heessen HJL, Hislop JRG (1998) Atlas of North Sea fishes. Based on bottom trawl surveys data from the years 1985-1987. ICES Coop Res Rep 194:1-268

Lastein L (1992) Hydrographic investigations on the Faroe Bank 1985-1992. ICES CM C:1-17

Livingston PA, Tjelmeland S (2000) Fisheries in boreal ecosystems. ICES J Mar Sci 57:619-627

Love RM, Robertson I, Lavéty J, Smith GL (1974) Some biochemical characteristics of cod (Gadus morhua L.) from the Faroe Bank compared with those from other fishing grounds. Comp Biochem Physiol 47B:149-161

Macpherson E, Duarte CM (1985) Bathymetric trends in demersal fish size: Is there a general relationship? Mar Ecol Prog Ser 27:99-107

Macpherson E, Gordoa A (1996) Biomass spectra in benthic fish assemblages in the Benguela System. Mar Ecol Prog Ser 138:27-32

Magurran AE (1988) Ecological diversity and its measurement. Croom Helm, London

Mahon R, Brown SK, Zwaneburg KCT, Atkinson DB and 6 others (1998) Assemblages and biogeography of demersal fishes of the east coast of North America. Can J Fish Aquat Sci 55:1704-1738

Marrett NR, Haedrich RL (1997) Deep-sea demersal fish and fisheries. Chapman \& Hall, London

Mattiangeli V, Bourke EA, Ryan A, Mork J, Cross TF (2000) Allozyme analyses of the genus Trisopterus: Taxonomic status and population structure of the poor cod. J Fish Biol 56:474-494

Mattiangeli V, Galvin P, Ryan AW, Mork J, Cross TF (2002) Population genetics of Atlantic poor cod (Trisopterus minutus) based on minisatellite DNA analysis: Further evidence for an isolated population at the Faroe Bank. Fish Res (in press)

McClatchie S, Millar RB, Webster F, Lester PJ, Hurst R, Bagley N (1997) Demersal fish community diversity off New Zealand: Is it related to depth, latitude and regional surface phytoplankton? Deep-Sea Res 44:647-667

Nielsen JG, Bertelsen E, Nystrøm BO (1992) Fish around Greenland (Fisk i Grønlandske farvande). Atuakkiorfik, Nuuk (in Danish)

Nørrevang A, Brattegard T, Josefson AB, Snelli JA, Tendal OS (1994) List of BIOFAR stations. Sarsia 79:165-180

Pianka ER (1988) Evolutionary ecology. Harper \& Row, New York

Editorial responsibility: Otto Kinne (Editor),

Oldendorf/Luhe, Germany
Pope JG, Knights BJ (1982) Comparison of length distributions of combined catches of all demersal fishes in surveys in the North Sea and Faroe Bank. Can Spec Publ Fish Aquat Sci 59:116-118

Rae BB (1939) Lemon soles at Faroe, 1923-1938. Rapp P-V Reun Cons Inst Explor Mer 109:15-27

Rogers SI, Millner RS (1996) Factor effecting the annual abundance and regional distribution of English inshore demersal fish populations: 1973 to 1995. ICES J Mar Sci 53: 1094-1112

Scott JS (1982) Depth, temperature and salinity preferences of common fishes of Scotian Shelf. J Northwest Atl Fish Sci 3: 29-39

Simonsen (1999) Tides and tidal simulation in the area around the Faroe Islands 166. GEM, Tórshavn, p 1-106

Snelgrove PVR, Haedrich RL (1985) Structure of the deep demersal fish fauna off Newfoundland. Mar Ecol Prog Ser 27:99-107

Stefanescu C, Rucabado J, Lloris D (1992) Depth-size trends in western Mediterranean demersal deep-sea fishes. Mar Ecol Prog Ser 81:205-213

Strubberg AC (1916) Marking experiment with cod at the Faroes. Medd Dan Fisk-Havunders 5:1-125

Strubberg AC (1933) Marking experiment with cod at the Faroes. Medd Dan Fisk-Havunders 9:1-36

Swain DP (1993) Age- and density-dependent bathymetric pattern of Atlantic Cod (Gadus morhua) in the Southern Gulf of St. Lawrence. Can J Fish Aquat Sci 50:1255-1264

SYSTAT (1998) SYSTAT 8.0 for Windows, Statistic PC program. Prentice-Hall, New York

Tåning ÅV (1940) Migration of cod marked on the spawning places off the Faroes. Medd Dan Fisk-Havunders 10: $3-52$

Uiblein F, Bordes F, Castillo R (1996) Diversity, abundance and depth distribution of demersal deep-water fishes off Lanzarote and Fuerteventura, Canary Islands. J Fish Biol 49:75-90

Ursin E (1984) On the growth parameters of Atlantic cod as function of body size. Dana 3:1-20

Whitehead PJP, Bauchot ML, Hureau JC, Nielsen J, Tortonese E (1984) Fishes of the North-eastern Atlantic and the Mediterranean. UNESCO, Paris

Wootton RJ (1990) Ecology of teleost fishes. Chapman \& Hall, London

Submitted: August 23, 2000; Accepted: February 19, 2002 Proofs received from author(s): July 23,2002 